\title{
Otoliths morphology and age-record in Bagre panamensis (Siluriformes: Ariidae) inhabiting at the southeast of Gulf of California
}

\author{
Juan Antonio Maldonado-Coyac ${ }^{1}(\mathbb{D})$, Rebeca Sánchez-Cárdenas ${ }^{2}(\mathbb{D})$, Jorge Saúl Ramírez-Pérez ${ }^{2}$ \\ Luis Antonio Salcido Guevara ${ }^{2} \mathbb{D}$, Karla Paola Valdez-Núñez ${ }^{3}$ \\ Armando Pérez-Centeno ${ }^{4} \mathbb{D}$ \& Maria de los Angeles Maldonado-Amparo ${ }^{2}(\mathbb{D}$ \\ ${ }^{1} \mathrm{Ph} . \mathrm{D}$. student, Posgrado en Ciencias en Recursos Acuáticos \\ Universidad Autónoma de Sinaloa, Mazatlán, Sinaloa, México \\ ${ }^{2}$ Facultad de Ciencias del Mar, Universidad Autónoma de Sinaloa, Mazatlán, Sinaloa, México \\ ${ }^{3}$ Universidad Politécnica de Sinaloa, Mazatlán, Sinaloa, México \\ ${ }^{4}$ Departamento de Física, Centro Universitario de Ciencias Exactas e Ingenierías \\ Universidad de Guadalajara, Guadalajara, Jalisco, México \\ Corresponding author: Rebeca Sánchez-Cárdenas (rsanchez@uas.edu.mx)
}

\begin{abstract}
Among Bagre genera, there is a high variation in the estimation of age, a concern due to overexploitation risk in fisheries because of age underestimation. Bagre panamensis is an important fishery resource of the Mexican Pacific and the Gulf of California. Its age is known from otoliths, but its accuracy needs to be confirmed, and the periodicity of the otoliths record validated. The external morphology, some microstructure attributes, and age record of B. panamensis' otoliths were described from 371 specimens collected southeast of the Gulf of California. The lapilli otoliths were larger than the sagittae and asterisci otoliths. The lapilli otoliths present aragonite crystals with a prismatic shape, and their growth is radial, from the core to the otolith edge. The lapilli otoliths form an annual growth ring, defined by the slowdown in the growth that occurs during April to July, during the breeding season. The ages of the individuals ranged from 1 to 15 years, and the applied method is considered adequate and accurate for its estimation (otolith cross-sectioning and red-neutral staining).
\end{abstract}

Keywords: Bagre panamensis; sea catfish; lapillus otolith; growth rings; aragonite crystals; accurate age method; otolith staining

\section{INTRODUCTION}

Otoliths are structures used for balance and hearing in all teleost fish (Campana 1999). They are composed of inorganic material ( $>90 \%$ calcium carbonate; Campana 1999 ) and $\leq 10 \%$ of organic material (glycoproteins, proteoglycans, and collagens; Lundberg et al. 2015), which grows throughout the life of fish (SchulzMirbach et al. 2018). Fish have three different pairs of otoliths (sagitta, lapillus, and asteriscus) that can be developed by any combination of the three most common forms (calcite, aragonite, or valerite) in which calcium carbonate crystallizes (Gauldie 1993, Oliveira et al. 1996, Pracheil et al. 2019, Thomas \& Swearer 2019). These can be located in membranous chambers (saccule, utricle, and lagena) connected by semicircular canals in the inner ear of fish (Campana 1999, SchulzMirbach et al. 2018). In most fish species, sagitta otolith is the largest and it is the most frequently used in estimating age (Panfili et al. 2002). However, in the superorder Ostariophysi including the sea catfishes (Siluriformes: Ariidae), the lapilli otoliths tend to be larger and more robust (Assis 2005, Diogo 2005) and they are the most suitable structures for fish age studies (Maciel et al. 2018), by the method of cutting, polishing and defining the periodicity deposition of material (Reis

Corresponding editor: Alejandra Volpedo 
1986, Cheraghi-Shevi et al. 2015, Maciel et al. 2018, Flinn et al. 2019; Table 1).

The knowledge of fishes age is necessary for growth rate, mortality rate, and productivity estimates (Cailliet et al. 2001, Campana 2001, Piddocke et al. 2015), particularly for biomass yield estimation and monitoring fisheries and aquaculture for sustainable management purposes. In Mexico, 25 sea catfishes species have been registered to inhabit the Pacific Ocean and the Gulf of California and 30 species in the Atlantic Ocean and the Caribbean waters (Marceniuk \& Ferraris 2003, Robertson \& Allen 2015). Some of them are currently fished mainly by Mexican small-scale fisheries (DOF 2012, 2018). Bagre panamensis (Gill, 1863) (Siluriformes: Ariidae) has been one of the most intensively exploited species (Arreguín-Sánchez \& Arcos-Huitrón 2011) and also it is part of bycatch of the industrial shrimp fishery (Amezcua et al. 2006, López-Martínez et al. 2010, Muro-Torres \& Amezcua 2011). It is worth mentioning that nowadays, there is a growing interest in their conservation and responsible use in fisheries and aquaculture (Maldonado-Coyac et al. 2018), but their management is still incipient.

The sea catfish B. panamensis is a benthopelagic fish widely distributed from southern California, USA, the Gulf of California to northern Peru (Robertson \& Allen 2015). Previous studies of B. panamensis from the southeastern Gulf of California have defined age by counting growth rings in whole lapilli otoliths without any treatment (Table 1). The age definition from whole otoliths could be easy and accurate in young individuals (Khan et al. 2016). But it is impossible to visualize all growth rings in older individuals (i.e. age >10; VanderKooy 2009). Since the growth rings are more overlapping near the edge of older otoliths, and usually, the age could be underestimated (Panfili et al. 2002, Easey \& Millner 2008, Volpedo \& Vaz-dos-Santos 2015, Khan et al. 2016). Therefore, there is a greater interpretation error (Campana 2001). While, in the youngest individuals could be difficult to identify the first annual growth ring (i.e. Brachyplatystoma rousseauxii) due to the presence of false rings (Hauser et al. 2018). Unfortunately, the process of estimating fish age based on any bony structure incorporates error due to subjectivity which originates with the preparation and interpretation of the periodic features in the calcified structures, and even in the same structure as the otolith, results in age estimates can differ among researchers (Campana 2001). In fisheries, particularly, this is a concern due to an aging error that can contribute to overexploitation of a population or species, often because age underestimation (rather than overestimation) results in overly optimistic estimates growth and mortality rate (review by Campana 2001).
There is a high variation in age estimation among sea catfishes in the Ariidae family and even in Bagre genera, with maximum ages from 3.5 to 36 years. Even different studies have gotten maximum ages differing by more than $50 \%$ in the same species. In Bagre marinus, the maximum ages of 10, 24, and 25 years have been defined, considering very close maximum sizes $(55.7 \mathrm{~cm}$ in total length, $57.7 \mathrm{~cm}$ in furcal length, and $55 \mathrm{~cm}$ in total length, respectively) (Table 1).

In this context, it is not always appropriate to use a unique method to estimate the age (Beamish \& McFarlane 1983, Maciel et al. 2018). It is recommended to re-estimate the age using improved or better methods. The cross-sectioning and neutral-red staining methods have been widely used to improve the contrast of growth rings and to estimate the age in sagittae otoliths of several marine fish species (Richter \& Mcdermott 1990, Arneri et al. 1998, 2001, Franks et al. 2001, Peltonen et al. 2002, Easey \& Millner 2008), and therefore to reduce the interpretation error (Easey $\&$ Millner 2008). While scanning electron microscopy (SEM) is a powerful tool that provides useful information about the structure and composition of fish otoliths, even if daily resolution is required (Panfili et al. 2009). In this sense and using these mentioned techniques, the age-record in lapillus otolith of $B$. panamensis and some morphological attributes of the external shape and microstructure of inorganic crystals of otoliths were described.

\section{MATERIALS AND METHODS}

A monthly sample of 10 to 49 specimens (371 total sample) of Bagre panamensis was collected from Mazatlán, Sinaloa, from September 2014 to November 2015 and January 2015, with the support of small-scale fishery. The total length (TL), eviscerated body weight (We), and sex of each organism were recorded, and lapilli otoliths were extracted, washed with water, marked, and stored to estimate age. Also, gonads weights were registered $(\mathrm{Gw})$.

The three pairs of otoliths (lapillus, sagitta, and asteriscus) from 10 individuals were extracted, photographed, and identified in order to describe their external morphology according to Martínez \& Monasterio de Gonzo (1991), Volpedo \& Echeverría (2000), Acero \& Betancur (2007), Chen et al. (2011), Aguilera et al. (2013), Santificetur et al. (2017) and Volpedo et al. (2017). Also, these lapilli otoliths were prepared to observe their microstructure using a Tescan MIRA 3 LMU scanning electron microscope; this procedure consisted of embedding the lapillus otolith in resin and cutting them transversely across the core with a circular diamond-tipped blade. Right away, the cut 
Table 1. Some age studies realized using lapilli otoliths of sea catfishes of Ariidae family, Siluriformes. NS: not specified, TL: total length, FL: fork length.

\begin{tabular}{|c|c|c|c|c|c|}
\hline \multirow[b]{2}{*}{ Species and aging method } & \multirow[b]{2}{*}{ Sex } & \multicolumn{2}{|c|}{ Maximum } & \multirow[b]{2}{*}{ Country } & \multirow[b]{2}{*}{ Reference } \\
\hline & & $\begin{array}{l}\text { Age } \\
(\mathrm{yr})\end{array}$ & $\begin{array}{l}\text { Length } \\
\text { (cm) }\end{array}$ & & \\
\hline $\begin{array}{l}\text { Whole otolith and whole operculum } \\
\text { Plicofollis tenuispinis (Day, 1877) } \\
\text { Whole otolith }\end{array}$ & Both & 3.5 & $41 \mathrm{TL}$ & India & Dan (1981) \\
\hline Bagre bagre (Linnaeus, 1766) & Both & 6 & $42 \mathrm{TL}$ & Brazil & Costa \& Juras $(1981,1982)$ \\
\hline Ariopsis guatemalensis (Günther, 1864) & Both & 6 & 43.4 FL & Mexico & Warburton (1978) \\
\hline Occidentarius platypogon (Günther, 1864) & Both & 8 & $52.5 \mathrm{TL}$ & Mexico & Muro-Torres (2011) \\
\hline Bagre panamensis & Both & 8 & $50.5 \mathrm{TL}$ & Mexico & Muro-Torres (2011) \\
\hline Sectioned otolith & & & & & \\
\hline Netuma thalassina (Rüppell, 1837) & Both & 11 & NS & India & Dmitrenko (1975) \\
\hline Netuma thalassina & Both & 19 & NS & Kuwait & Bawazeer (1987) \\
\hline Plicofollis dussumieri (Valenciennes, 1840) & Both & 12 & 76.7 FL & Iran & Cheraghi-Shevi et al. (2015) \\
\hline Galeichthys feliceps (Valenciennes, 1840) & Male & 16 & 37.9 FL & South Africa & Tilney (1990) \\
\hline Galeichthys feliceps & Female & 18 & $37.9 \mathrm{FL}$ & South Africa & Tilney (1990) \\
\hline Galeichthys ater (Castelnau, 1861) & Male & 15 & $31.9 \mathrm{FL}$ & South Africa & Tilney (1990) \\
\hline Galeichthys ater & Female & 15 & $31.9 \mathrm{FL}$ & South Africa & Tilney (1990) \\
\hline Genidens barbus (Lacépède, 1803) & Female & 36 & $98 \mathrm{TL}$ & Brazil & Reis (1986b) \\
\hline Genidens genidens (Cuvier, 1829) & Male & 11.5 & $38 \mathrm{TL}$ & Brazil & Maciel et al. (2018) \\
\hline Genidens genidens & Female & 11.5 & $47 \mathrm{TL}$ & Brazil & Maciel et al. (2018) \\
\hline Ariopsis felis (Linnaeus, 1766) & Male & 20 & $34 \mathrm{TL}$ & USA & Armstrong et al. (1996) \\
\hline Ariopsis felis & Female & 23 & $43.9 \mathrm{FL}$ & USA & Armstrong et al. (1996) \\
\hline Ariopsis felis & Both & 24 & $49.2 \mathrm{TL}$ & USA & Flinn et al. (2019) \\
\hline Bagre marinus (Mitchill, 1815) & Male & 18 & 49.5 FL & USA & Armstrong et al. (1996) \\
\hline Bagre marinus & Female & 24 & $57.7 \mathrm{FL}$ & USA & Armstrong et al. (1996) \\
\hline Bagre marinus & Both & 10 & $55.7 \mathrm{TL}$ & USA & Flinn et al. (2019) \\
\hline Bagre marinus & Male & 14 & $50 \mathrm{TL}$ & USA & Miguez (2019) \\
\hline Bagre marinus & Female & 25 & $55 \mathrm{TL}$ & USA & Miguez (2019) \\
\hline
\end{tabular}

faces were polished using 1000,300 , and $50 \mathrm{~nm}$ alumina powders in order to eliminate possible scratches on the surface of the structure. Subsequently, the otolith sections were immersed in $1 \% \mathrm{HCl}$ solution for $25 \mathrm{~s}$, washed with double distilled water, and dried to reveal the microstructure. Then, the otoliths were mounted on a holder-sample by conductive carbon film, and the surface was coated with a thin layer of gold $(\mathrm{Au})$ of about $2 \mathrm{~nm}$ to avoid the electron charge effect. The images were recorded by utilizing SEM. Then, some morphologies and attributes of lapilli otoliths microstructure were described according to Tomás \& Geffen (2003), Cermeño et al. (2006), Panfili et al. (2009), and Green et al. (2009). The microstructures were measured from the digital images using SigmaScan Pro, version 5.0 (Systat Software Inc.) software.

One lapillus otolith (left) from all collected otoliths pairs was first photographed whole beside a scale $(0.01$ $\mathrm{mm}$ precision). It was then embedded in epoxy resin and cut transversely across the core using a circular diamond-tipped blade. One cut face of each otolith was stained for $30 \mathrm{~min}$ in a neutral-red solution prepared with $100 \mathrm{~mL}$ of distilled water, $0.2 \mathrm{~g}$ of neutral red, 0.5 $\mathrm{mL}$ of glacial acetic acid, and $1 \mathrm{~g}$ of sodium chloride (Easey \& Millner 2008). It was washed with distilled water to remove solution excess and photographed. The neutral-red staining decalcified a thin layer of the otoliths' cut-face surface to expose the protein matrix to be stained by the neutral-red (Arneri et al. 1998, Easey \& Millner 2008). The staining is less intense where there is a lower concentration of proteins and higher concentration of inorganic material (mainly calcium carbonate crystals), and vice versa (Richter \& McDermott 1990, Arneri et al. 1998, Easey \& Millner 2008).

The photographs of whole and cut-stained otoliths were obtained through a stereomicroscope with reflected light. Two independent readers counted the otoliths growth rings on the digital images of cut-stain otolith; one growth ring was composed of red-light (RL) and red-dark (RD) adjacent bands (Fig. 1). It was also recor- 


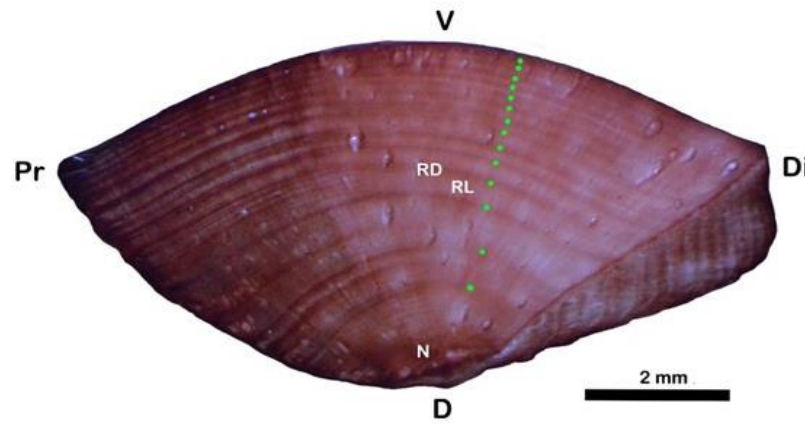

Figure 1. Stain cross-section of right otolith lapillus of Bagre panamensis, observed under reflected light. Position of otolith; D: dorsal, V: ventral, Pr: proximal, and Di: distal. Structures; N: nucleus, RL: red-light band, RD: red-dark band. Green dots indicate the growth rings. Neutral-red staining.

ded if the otolith had an RL or RD band at the edge. Additionally, particularities and anomalies of the growth rings were identified and described according to Cermeño et al. (2006, 2008), Green et al. (2009), ICES (2009), Cerna \& Plaza (2016), and Hauser et al. (2018), and their occurrence was explored concerning the number of growth rings by sex. The diameters of otolith were measured from the digital images of the whole otolith using SigmaScan Pro, version 5.0 (Systat Software Inc.) software (Fig. 2a).

The ring counting accuracy was evaluated with the average error rate (APE, Beamish \& Fournier 1981) and the coefficient of variation (CV, Chang 1982). The monthly relative frequency $(\%)$ of the percentage of $\mathrm{RL}$ and RD bands at the otolith edge by sex was explored throughout the year to define the deposition periodicity of the growth rings (Reis 1986, Fowler 2009, Maciel et al. 2018). Moreover, the frequencies were correlated with the gonadosomatic index (GSI = Gw / We $\times 100$; Pinheiro et al. 2006) to explore the interaction between reproductive and growth processes, using the Spearman's rank correlation coefficient $\left(\mathrm{r}_{\mathrm{s}}\right)$ and a $t$-test with n-2 degree of freedom and a significance level $P$ $=0.05$ (Zar 2010). Furthermore, the statistical relations of otoliths diameter with TL and the number of growth rings were defined using linear and power models, respectively, fitted by the least-squares method (Zar 2010). Finally, the age structures of B. panamensis of

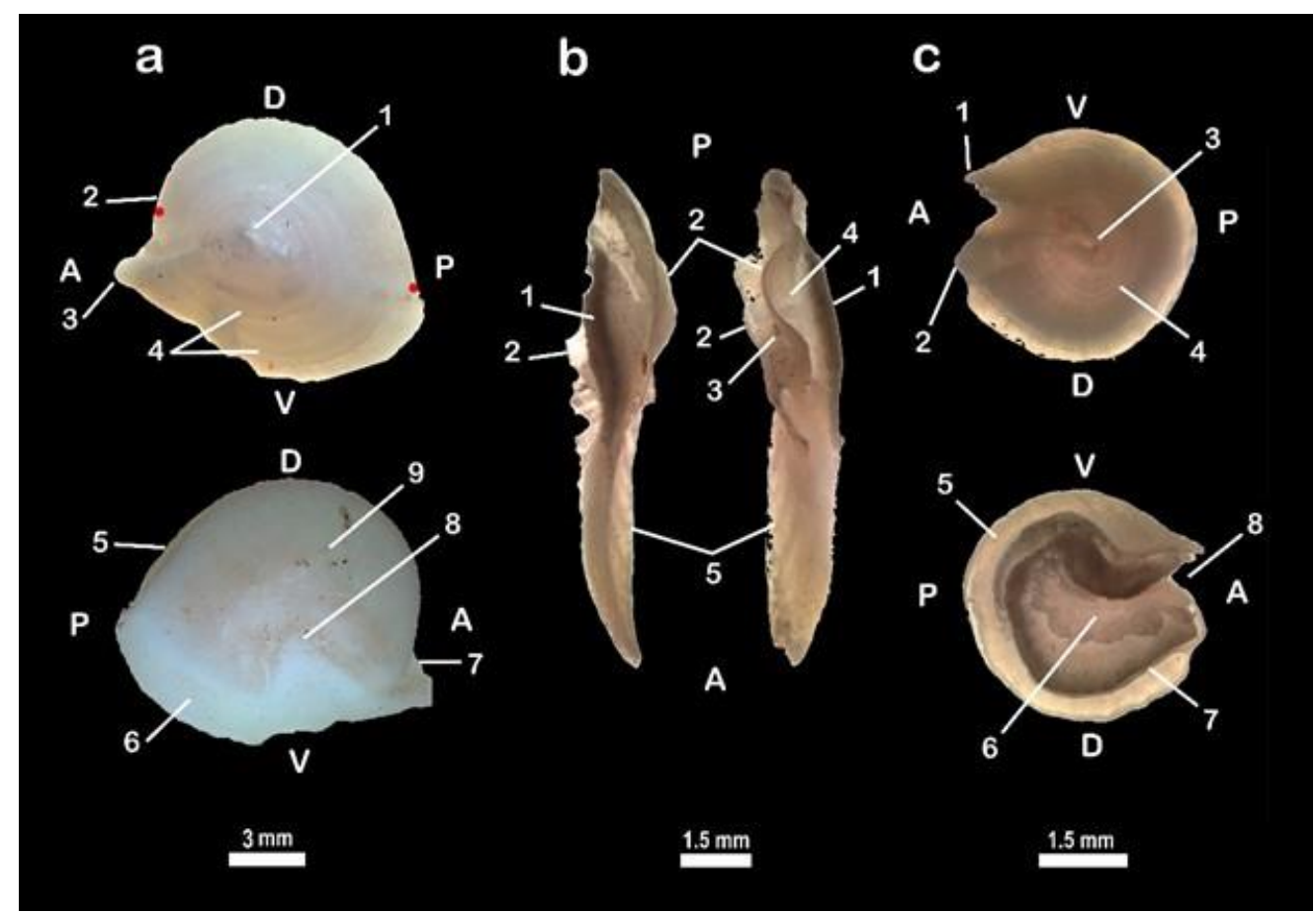

Figure 2. Morphological characteristics of the otoliths of the sea catfish Bagre panamensis. Position of otoliths: D: dorsal, V: ventral, A: anterior, and P: posterior. a) Lapillus: upper dorsal face and lower ventral face. 1) Core, 2) antirostrum, 3) rostrum, 4) growth rings, 5) semipronunciated anterodistal ditch, 6) superficial mesial depression, 7) internal mesial curve, 8) indistinct acoustic sulcus, 9) gibbus maculae. Red dots indicate the extremes of the otolith's diameter; b) Sagitta: upper dorsal face and lower ventral face. 1) Ventral wing, 2) dorsal wing, 3) dorsal fissure, 4) ventral fissure, 5) growth rings; c) Asteriscus: upper dorsal face and lower ventral face. 1) Face, 2) antirostrum, 3) core, 4) growth ring, 5) lobus major, 6) sulcus "acoustic fossa", 7) canaliculum, 8) excisura "opening". 
each sex were presented and described. The Kolmogorov-Smirnov two-sample test was performed to compare age structure between females and males, with a significance level $P=0.05$ (Zar 2010).

\section{RESULTS}

\section{Otoliths}

The lapilli of the sea catfish Bagre panamensis are large (>12 mm), globose or compressed, thick circle, with the rostrum more developed than the antirostrum; it has growth marks on the dorsal surface, difficult to identify in old fish because they overlap near the edge (Fig. 2a). While the sagitta is elongated $(<10 \mathrm{~mm})$, the anterior margin is more pointed than the posterior margin. It has a pair of dorsal and ventral wings that twist from the middle to the posterior margin of the otolith; it is a fragile structure. Some growth rings in the middle part up to the anterior margin of the otolith are difficult to identify (Fig. 2b). On the other hand, the asteriscus is a tiny structure $(4.5 \mathrm{~mm})$, smaller than the lapillus and sagitta. It is very fragile, translucent, and rounded, with slightly wavy edges, angular face, while the antirostrum is more or less pointed and little developed, existing between both a wide excisura; its acoustic fosse has granulations (Fig. 2c).

Under the SEM, the low-magnification microphotography of lapillus otolith's cut face showed dark and whitish bands (Figs. 3a-b). Darker areas appeared from electron absorption associated with the presence of insoluble organic material. Dark tonalities are seen throughout the otolith (Fig. 3a), including in whitish bands, indicating that the organic matrix is distributed throughout the otolith but with greater concentration in the darker areas. The lapilli otoliths present aragonite crystals with prismatic shape and long grouped (Figs. $3 \mathrm{e}-\mathrm{f}$ ), and the prismatic growth is radial, from the core to the otolith edge (Figs. 3c-d). The surface of aragonite crystals is smooth, and the prismatic form is variable (square, rectangular, pentagonal, hexagonal, or irregular) (Figs. 3g-h). The width of aragonite crystals is approximately $3.7 \pm 1.3 \mu \mathrm{m}$.

\section{Growth rings periodicity}

A total of 371 lapilli otoliths from 176 males and 195 females of B. panamensis were suitably cut, stained, and examined. Lapilli otoliths form growth rings with an RL band wider and with less fixation of red-neutral dye. An indication of greater calcium crystals accumulation into the protein matrix due to growth. While the RD band of growth rings was the narrower and with greater fixation of red-neutral dye, indicating a minor accumulation of calcium crystals into the protein matrix due to growth slowdown (Fig. 1). The monthly RL and RD bands frequencies at the edge of the otolith show that one growth ring is formed annually because their behavior presented one periodical oscillation per year. The RD bands at the edge of the otolith (growth slowdown) were less frequent from October to February. Their frequencies began to increase during March, reaching a maximum frequency during April to July (growth slowdown season) decreased in August and September. The behavior of RL bands frequencies was reversed and presented the higher frequencies during August to March (fast-growth season) (Fig. 4). The growth slowdown season coincides with the highest values of the GSI in both sexes of B. panamensis, supported by a positive correlation between RD bands frequencies at the edges and the GSI (Fig. 4, Table 2).

\section{Particularities of growth rings}

Some growth rings of lapilli otoliths in B. panamensis presented different RL and RD bands composition in $35 \%$ of individuals concerning the previously described. Whereby, three different types of growth rings (GR) were identified, characterized by single (S, normal), double (D), and triple (T) RD bands in their composition (Fig. 5a). The additional RD bands in D and $\mathrm{T}$ growth rings are discontinuous. That is, the bands do not show continuity around the entire otolith (Fig. $5 a)$. The $T$ growth rings were observed in the first to fifth rings in males and the first to fourth in the females, but the highest frequency (42\%) was observed in the second ring in both sexes (Fig. 5b). The D growth rings were observed from the first to the ninth rings (decreased in the latter) (Fig. 5b), and they were more frequent $(31 \%)$ than grow rings $\mathrm{T}(4 \%)$.

Additionally, width alteration of one RL band was detected between the third and sixth growth rings of lapillus otolith in $8.6 \%$ of individuals. The width alteration is seen as a widening of the RL band from the right posterior margin to the middle part of the otolithic structure (Fig. 6).

\section{Rings counting and otolith size relationships}

The processing and ring counting of 371 lapilli otoliths was performed without difficulty. These otoliths have 4.6 to $12.1 \mathrm{~mm}$ in diameter. The accuracy of the ring counting between both readers was high (APE $=5.8 \%$ and $\mathrm{CV}=8.1 \%$ ). The individuals presented 13 to 49.1 $\mathrm{cm}$ in total length (TL) and one to 15 years old (age, AG). The relationships of lapillus otolith diameter (OD) as a function of TL and AG showed high coefficients of determination, demonstrating a clear positive proportionality between the increase in OD concerning the TL and AG (Fig. 7). The relationship between OD and TL was linear in both sexes $\left(\mathrm{r}^{2}=0.7825\right.$ 

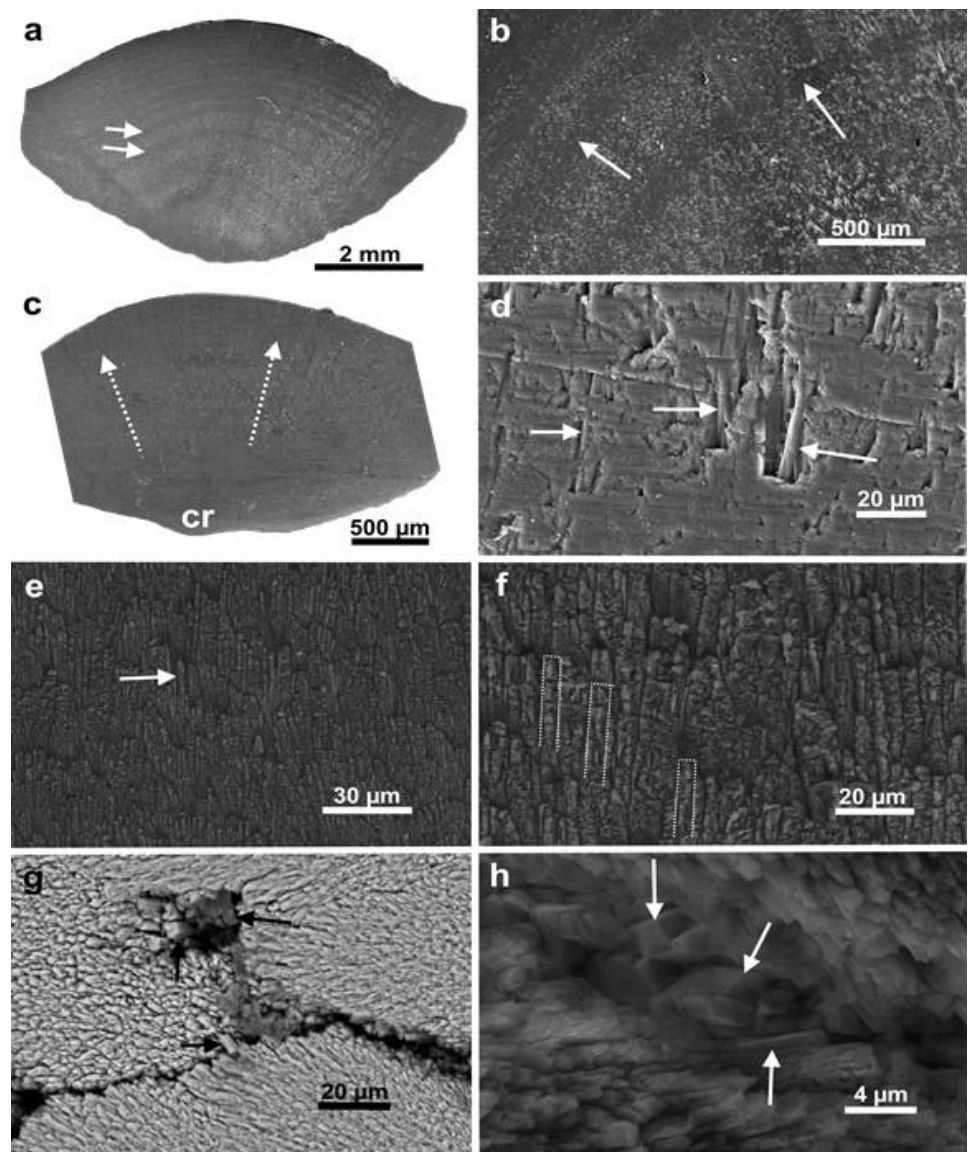

Figure 3. Scanning electron micrographs of the sea catfish Bagre panamensis' lapilli otoliths. a-b) Dark (arrows) and whitish bands on the otolith's cut face, c-d) stretch marks from the core (cr) indicating the radial growth (dotted arrows) of the aragonite crystals (arrows with solid line), e-f) the long grouped aragonite crystals (arrow and dotted marks), g-h) view of aragonite crystals that reveal the variable prismatic form (arrows).

a

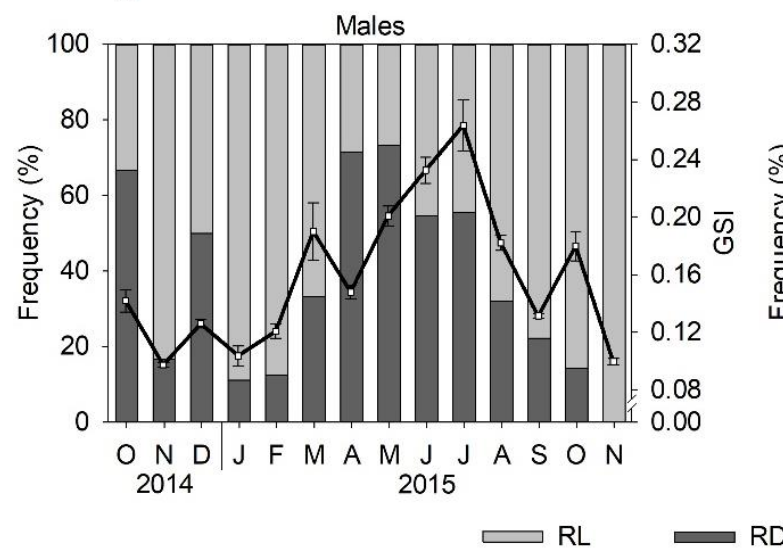

b

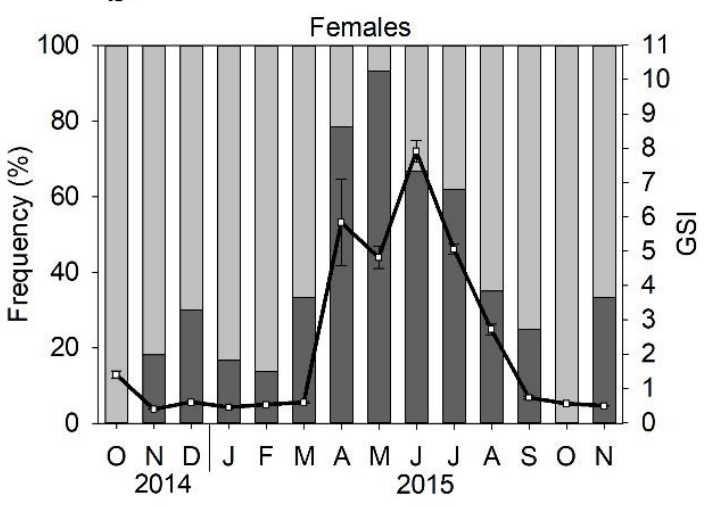

Figure 4. Monthly red-light (RL) and red-dark (RD) bands frequencies at the otoliths edge and monthly average of gonadosomatic index (GSI) of males (a) and females (b) of Bagre panamensis from the southeastern Gulf of California. Standard error (bars).

males and $\mathrm{r}^{2}=0.8752$ females) (Fig. 7a). Meanwhile, the relationship between OD and AG presented a suitable fit to the power model in both sexes $\left(\mathrm{r}^{2}=\right.$ 0.7788 males and $\mathrm{r}^{2}=0.7712$ females) (Fig. $7 b$ ). 
Table 2. Correlations between the monthly red-light (RL) and red-dark (RD) bands frequencies at the otoliths edge and monthly average of gonadosomatic index (GSI) of males and females of Bagre panamensis of southeastern Gulf of California. n: data number, $\mathrm{r}_{\mathrm{s}}$ : Spearman's rank correlation coefficient, t: $t$-test, $P: P$-value, asterisk $\left({ }^{*}\right)$ indicates a significant correlation $(P<0.05)$.

\begin{tabular}{lcrrc}
\hline Correlations & $\mathrm{n}$ & \multicolumn{1}{c}{$\mathrm{r}_{\mathrm{s}}$} & \multicolumn{1}{c}{$t_{(\mathrm{n}-2)}$} & $P$ \\
\hline Males & & & & \\
$\quad$ RD band $v s$. GSI & 14 & 0.6703 & 3.1292 & $0.008704^{*}$ \\
$\quad$ RL band $v s$. GSI & 14 & -0.6703 & -3.1292 & $0.008704^{*}$ \\
Females & & & & \\
$\quad$ RD band vs. GSI & 14 & 0.6828 & 3.2376 & $0.007118^{*}$ \\
$\quad$ RL band $v s$. GSI & 14 & -0.6828 & -3.2376 & $0.007118^{*}$ \\
\hline
\end{tabular}
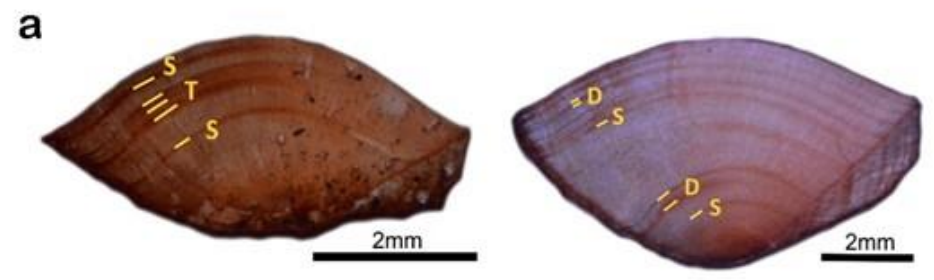

b

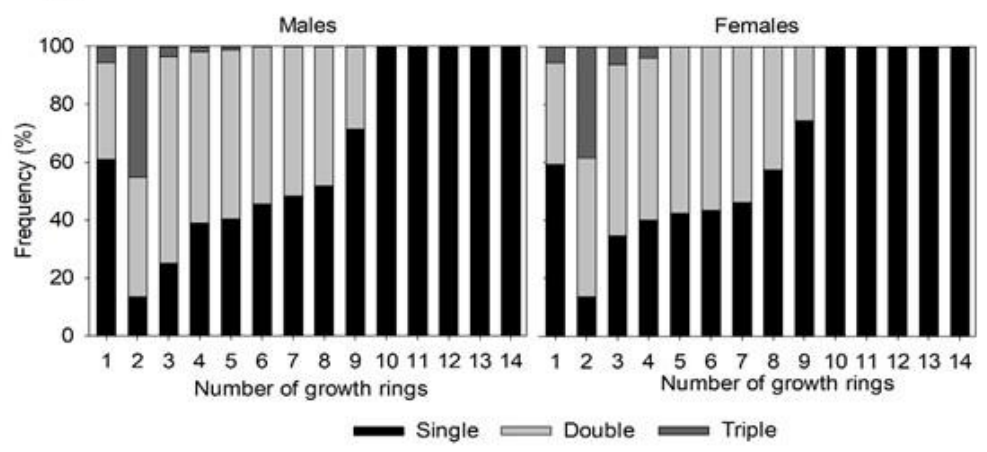

Figure 5. a) Cross-sections of lapillus of the Bagre panamensis with different types of growth rings, S: single, T: triple, D: double, b) relative frequency of the different type growth rings (single, double, and triple) regarding the total number of growth rings.

\section{Age structure}

The age structure of the B. panamensis sample from the southeastern Gulf of California was composed of organisms from one to 14 years in females and one to 15 years in males. The five to nine years old individuals were the more frequent (Fig. 8). The age structures were similar between females and males $\left(D_{\max }=\right.$ $0.021329 ; P=0.10)$.

\section{DISCUSSION}

\section{Otoliths}

The descriptions made on Bagre panamensis otoliths correspond to that reported for freshwater catfishes
(Martínez \& Monasterio de Gonzo, 1988, 1991) and sea catfishes (Volpedo \& Echeverría, 2000, Acero \& Betancur 2007, Chen et al. 2011, Aguilera et al. 2013, Santificetur et al. 2017, Volpedo et al. 2017), in which the lapilli exceed in size the sagitta and asteriscus. The lapilli of the Ariidae is larger than the lapilli found in the Plotosidae, Horabagrus, and Archariidae catfishes (Oliveira et al. 2001, Diogo 2005). The large size of the lapillus is attributed to the fact that this structure occupies the area corresponding to several bones of the cranial otic region (Oliveira et al. 2001, Diogo 2005), which allows it to expand within the cavity and increase its size. Hence, the lapillus otolith is one of the most used structures to estimate the age and growth of the catfishes. 

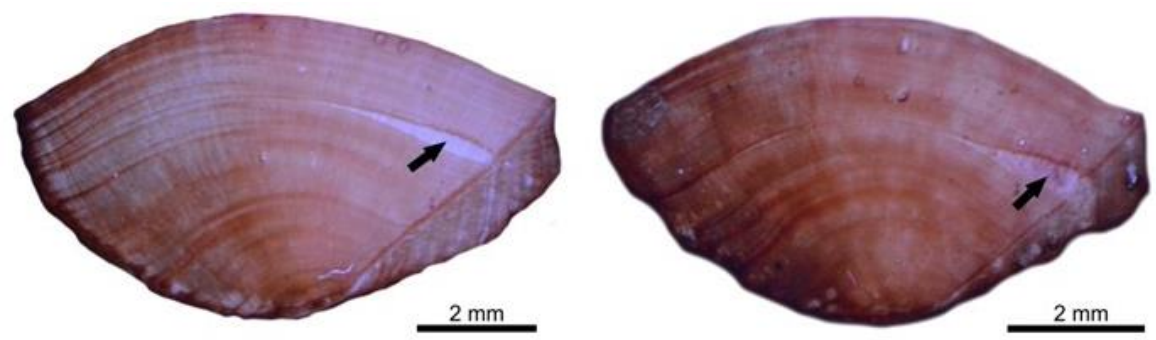

Figure 6. Cross-sections lapillus otolith of Bagre panamensis with width alteration of one red-light (RL) band (black arrows).
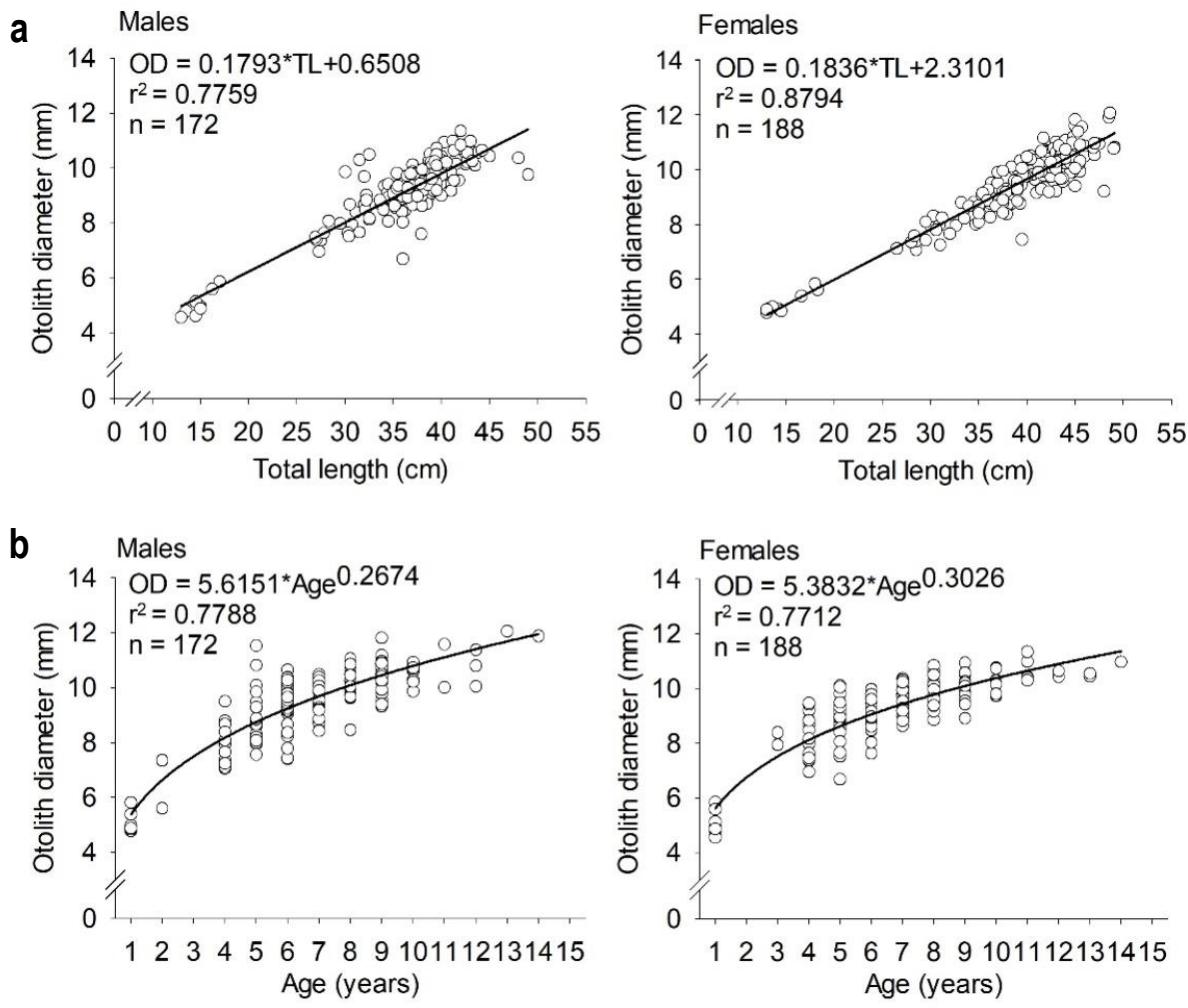

Figure 7. a) Relationship between the otolith diameter-total length, b) otolith diameter-age of males and females of Bagre panamensis in the southeast of the Gulf of California.

The lapilli otoliths presented aragonite microcrystals with a prismatic form, the typical shape of these structures (Tomás \& Geffen 2003, Panfili et al. 2009). In some acid-treated otoliths, the crystals were degraded partially or almost totally due to exposure with $\mathrm{HCl}$ (Cermeño et al. 2006, Green et al. 2009). The electron absorption was different along the otolith, revealing dark and whitish bands similar in width and shape to the RD and RL bands showed by the neutralred stain, respectively. Therefore, they are representing the same areas in the otoliths. The darker zones (dark bands) due to electron absorption are associated with insoluble organic material (Cermeño et al. 2006) in higher concentrations. While a more reddish stain (RD bands) due to neutral-red stain is attributed to a higher concentration of proteins (Richter \& McDermott 1990, Arneri et al. 1998, Easey \& Millner 2008). This coherence between the two methods supports that the narrower bands of rings otoliths (dark bands and RD bands) of $B$. panamensis present a higher concentration of proteins and a minor accumulation of aragonite crystals concerning the wider bands (whitish bands and RL bands).

\section{Growth rings periodicity}

B. panamensis forms one growth ring annually in lapilli otoliths. Similar to other species of sea catfishes (Reis 1986, Tilney 1990, Mehanna et al. 2012, Cheraghi-Shevi 


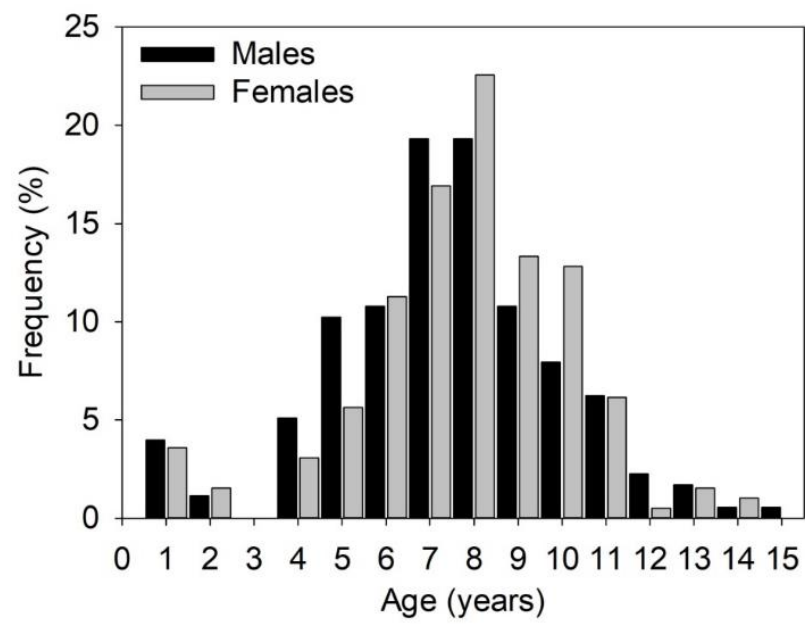

Figure 8. The age structure of males and females of the Bagre panamensis sample from the southeastern Gulf of California.

et al. 2015, Maciel et al. 2018, Flinn et al. 2019). The annual growth pattern of rings presented similar periodicity to the annual reproductive pattern, so the fast-growing season coincided with the time of reproductive rest. In contrast, the slowdown growth season was overlapped with the time of reproduction and oral incubation (eggs and offspring) of $B$. panamensis in the southeast of the Gulf of California (Muro-Torres 2011, Muro-Torres \& Amezcua 2011, Zavala-Leal et al. 2019). Similar results have been reported in the sea catfish Galeichthys feliceps and G. ater of South Africa coasts (Tilney 1990), Genidens barbus (Reis 1986), and G. genidens (Maciel et al. 2018) of Brazil coasts. They ensure that reproductive activity and oral incubation (eggs and offspring) entails a high energy expenditure (Rimmer \& Merrick 1983, Tilney 1990), and this is a critical factor in reducing the sea catfish growth rate (Reis 1986, Velasco \& Reis 2004, Velasco et al. 2007, Maciel et al. 2018).

\section{Particularities of growth rings}

The $\mathrm{S}$ growth rings were considered normal because they are the type of growth ring commonly found and counted to assess the age in fishes (Campana 2001, Green et al. 2009). The additional discontinuous RD bands in $\mathrm{D}$ and $\mathrm{T}$ growth rings were considered false bands since they were not continuously registered around the otolith. Hauser et al. (2018) recorded similar growth patterns and types of rings in lapillus otolith of the freshwater catfish Brachyplatystoma rousseauxii (Castelnau, 1855) from the Orinoco River, as in $B$. panamensis. The authors documented that it was difficult to define age due to $\mathrm{D}$ and $\mathrm{T}$ growth rings presence. They reported that the stress caused by the increased salinity in the Orinoco River during August and September and competition for food, and long periods of starvation were critical factors that led to the formation of these otoliths anomalies.

Similarly, D and T growth rings were found in the sagittae otoliths of adult fish of the American eel Anguilla rostrata (Lesueur, 1817) and the Swedish eel A. anguilla (Linnaeus, 1758), attributed to the stress caused by high-temperature levels and low oxygen concentrations during the summer, that cause slow-orstop growth and the deposition of false bands (ICES 2009). Likewise, D growth rings were found in daily growth rings of sagittae otoliths in juveniles of European anchovy Engraulis encrasicolus (Linnaeus, 1758) (Cermeño et al. 2006, 2008) and Peruvian anchovy E. ringens (Jenyns, 1842) (Cerna \& Plaza 2016). They contained a large amount of protein matrix (Cermeño et al. 2006), deposited as evidence of metamorphosis stages and habitat changes (MoralesNin \& Aldebert 1997, Tomás \& Panfili 2000).

The false bands' formation (discontinuous RD bands) and the width alteration of one RL band in lapillus otolith could be related to various biological process such as habitat change during the juvenile stage (from the ocean to estuarine systems and vice versa; Amezcua et al. 2006, Madrid-Vera et al. 2007), sexual maturity $(35.5 \mathrm{~cm} \mathrm{LT}$ in Muro-Torres \& Amezcua 2011; 3.8 years in Muro-Torres 2011), reproduction and oral incubation of offspring (Muro-Torres \& Amezcua 2011), and also with changes in environmental conditions (Beamish \& McFarlane 1983, Reis 1986, Velasco \& Reis 2004). Those otoliths structure alterations are occurring at the time in which such processes could also be occurring in B. panamensis. Those "alterations" are an abnormal change in the deposition of protein matrix (false bands) and the inorganic material (width alteration of RL band), and this alteration may occur during a short time since it is not fully developed around the otolith structure. Perhaps, those "alterations" are caused by a circumstantial and abnormal limitation (false bands) or availability (width alteration of RL band) of food or energy reserves during the fast growth and slowdown growth seasons, respectively.

\section{Rings counting and otolith size relationships}

The accuracy of ring counting was high, according to Campana (2001), and the growth rings were distinguishable, even in older individuals. However, the rings were closer together but the neutral-red staining provided adequate contrast. It is worth mentioning that neutral-red staining has been widely used to improve the contrast of growth rings and for the age study in cross-sections of sagittae otoliths of several marine fish species (Richter \& Mcdermott 1990, Arneri et al. 1998, 2001, Franks et al. 2001, Peltonen et al. 2002, Easey \& Millner 2008). 
The proper contrast of the growth rings and their clear temporal formation pattern in lapilli otoliths, in addition to the clear positive proportionality in the relationships of otolith size (OD) as a function of TL and $\mathrm{AG}$, confirm that lapilli otoliths are adequate structures to estimate the age and growth of $B$. panamensis as having been reported for other species of sea catfishes (Reis 1986, Tilney 1990, Mehanna et al. 2012, Cheraghi-Shevi et al. 2015) and freshwater catfishes (Hauser et al. 2018).

\section{Age structure}

The age structure of $B$. panamensis was composed of organisms between one to 15 years old. The most frequent ages in the sampled were five to nine years old, mainly adult organisms since $B$. panamensis reaches size and age of sexual maturity at $35 \mathrm{~cm}$ of TL and 3.8 years (Muro-Torres 2011, Muro-Torres \& Amezcua 2011).

The maximum observed age was 15 years, almost twice the maximum age recorded ( 8 years) by MuroTorres \& Amezcua (2011). Also, for B. panamensis in the same sampling area, despite that analyzed individuals in both studies had similar sizes (13 to 49.1 $\mathrm{cm}$ TL in the present study; 14 to $52 \mathrm{~cm}$ TL in MuroTorres \& Amezcua, 2011). This difference could be due to Muro-Torres \& Amezcua (2011) counted growth rings using the whole lapillus otolith. Because the growth rings can be masked and poorly distinguished toward the edge of the whole otoliths, fewer growth rings are counted. Whence, the age can be underestimated from whole otoliths, compared to the sectioned otoliths (Panfili et al. 2002, Easey \& Millner 2008, Volpedo \& Vaz-dos-Santos 2015). For the freshwater catfish Sperata aor (Hamilton, 1822), growth rings of whole lapilli otoliths are unclear in the otolith edge due to the curvature in older individuals causing underestimating age (Khan et al. 2016), and its cross-sectioned otoliths had more distinguishable growth rings than whole otoliths (Nazir \& Khan 2020). Also, for the sparid fish Argyrozona argyrozona (Valenciennes, 1830), the number of growth rings number is underestimated when using whole sagittae otoliths of fish older than ten years old concerning counts made from cross-sectioned otoliths (Brouwer \& Griffiths 2004).

Although growth ring counting from whole otoliths is a valid technique and still applied in several fish species (Volpedo \& Vaz-dos-Santos 2015), given the present study results and the notable differences with the previous studies, it is not recommended for age estimation in the sea catfish $B$. panamensis. Instead of that, the cross-sectioning and red-neutral staining of otoliths are more suitable for age estimation in $B$. panamensis, like in other fish species, to reduce the interpretation error and age underestimation (Campana 2001, Easey \& Millner 2008). It is worth noting that $B$. panamensis is a fishery resource in Mexico and is considered a species with aquaculture potential. The age data are important for fisheries and aquaculture management, such as estimating growth and mortality rate in productivity assessment. Moreover, the age underestimation (rather than overestimation) could cause overly optimistic productivity estimates that may contribute to overexploitation of a population in a fishery (review by Campana 2001) and inaccurate yield estimates in aquaculture.

\section{ACKNOWLEDGMENTS}

We thank the small-scale fishermen from Mazatlán, Sinaloa, for providing us with samples of sea catfish. JAMC thanks the National Council of Science and Technology (CONACyT) for a Ph.D. scholarship. Special thanks to Jorge Manuel Elenes Lizarraga for the English review of the manuscript.

\section{REFERENCES}

Acero-P., A. \& Betancur, R. 2007. Monophyly, affinities, and subfamilial clades of sea catfishes (Siluriformes: Ariidae). Ichthyological Exploration of Freshwaters, 18: 133-143.

Aguilera, O.A., Moraes-Santos, H., Costa, S., Ohe, F., Jaramillo, C. \& Nogueira, A. 2013. Ariid sea catfishes from the coeval Pirabas (Northeastern Brazil), Cantaure, Castillo (Northwestern Venezuela), and Castilletes (North Colombia) formations (early Miocene), with description of three new species. Swiss Journal of Palaeontology, 132: 45-68. doi: 10.100 7\%252Fs13358-013-0052-4

Amezcua, F., Madrid, J. \& Aguirre, H. 2006. Effect of the artisanal shrimp fishery on the ichthyofauna in the coastal lagoon of Santa Maria la Reforma, Gulf of California. Ciencias Marinas, 32: 97-109.

Arreguín-Sánchez, F. \& Arcos-Huitrón, E. 2011. La pesca en México: estado de la explotación y uso de los ecosistemas. Hidrobiológica, 21: 431-462.

Armstrong, M., Murphy, M.R., Muller, Harshany, D. \& Crabtree, R. 1996. A stock assessment of hardhead catfish, Arius felis, and gafftopsail catfish, Bagre marinus. Florida waters. Report to the Florida Marine Fisheries Commission Florida Department of Environmental Protection, Florida Marine Research Institute, StPetersburg, FL USA. [https://www.researchgate. net/publication/258031905_a_stock_assessment_of_h ardhead_catfish_arius_felis_and_gafftopsail_catfish_ bagre_marinus_in_florida_waters]. 
Arneri, E., Colella, S. \& Giannetti, G. 1998. A method for the age determination of two mediterranean sciaenids, Sciaena umbra (Linnaeus, 1758) and Umbrina cirrosa (Linnaeus, 1758). Rapport Commission Internationale pour l'Exploration Scientifique de la Méditerranée, 35: 366-367.

Arneri, E., Colella, S. \& Giannetti, G. 2001. Age determination and growth of turbot and brill in the Adriatic Sea: reversal of the seasonal pattern of otolith zone formation. Journal of Applied Ichthyology, 17: 256-261. doi: 10.1046/j.1439-0426.2001.0029 3.x

Assis, C.A. 2005. The utricular otoliths, lapilli, of teleosts: their morphology and relevance for species identification and systematics studies. Scientia Marina, 69: 259-273. doi: 10.3989/scimar. 2005.69n2259

Bawazeer, A.S. 1987. The fishery biology and management of the stock of chim, the giant sea catfish (Arius thalassinus), in Kuwait waters. Kuwait Bulletin of Marine Science, 9: 87-100.

Beamish, R.J. \& Fournier, D.A. 1981. A method for comparing the precision of a set of age determinations. Canadian Journal of Fisheries Aquatic Science, 38: 982-983. doi: 10.1139/f81-132

Beamish, R.J. \& McFarlane, G.A. 1983. The forgotten requirement for age validation in fisheries biology. Transactions of the American Fisheries Society, 112: 735-743. doi: 10.1577/1548-8659(1983)112\%3C735: TFRFAV\%3E2.0.CO;2

Brouwer, S.L. \& Griffiths, M.H. 2004. Age and growth of Argyrozona argyrozona (Pisces: Sparidae) in a marine protected area: an evaluation of methods based on whole otoliths, sectioned otoliths, and mark-recapture. Fisheries Research, 67: 1-12. doi: 10.1016/j.fishres. 2003.08.007

Cailliet, G., Andrews, A., Burton, E., Watters, D., Kline, D. \& Ferry-Graham, L. 2001. Age determination and validation studies of marine fishes: do deep-dwellers live longer? Experimental Gerontology, 36: 739-764. doi: 10.1016/S0531-5565(00)00239-4

Campana, S.E. 1999. Chemistry and composition of fish otoliths: pathways, mechanisms, and applications. Marine Ecology Progress Series, 188: 263-297.

Campana, S.E. 2001. Accuracy, precision, and quality control in age determination, including a review of the use and abuse of age validation methods. Journal of Fish Biology, 59: 197-242. doi: 10.1111/j.10958649.2001.tb00127.x

Cermeño, P., Morales-Nin, B. \& Uriarte, A. 2006. Juvenile European anchovy otolith microstructure. Scientia Marina, 70: 553-557.

Cermeño, P., Uriarte, A., Morales-Nin, B., Cotano, U. \& Álvarez, P. 2008. Setting up interpretation criteria for ageing juvenile European anchovy otoliths. Scientia
Marina, 72: 733-742. doi: 10.3989/scimar.2008.72n 4733

Cerna, F. \& Plaza, G. 2016. Daily growth patterns of juveniles and adults of the Peruvian anchovy (Engraulis ringens) in northern Chile. Marine and Freshwater Research, 67: 899-912. doi: 10.1071/ MF15032

Chang, W.Y.B. 1982. A statistical method for evaluating the reproducibility of age determination. Canadian Journal of Fisheries Aquatic Science, 39: 1208-1210. doi: 10.1139/f82-158

Chen, W., Al-Husaini, M., Beech, M., Al-Enezi, K., Rajab, S. \& Husain, H. 2011. Discriminant analysis as a tool to identify catfish (Ariidae) species of the excavated archaeological otoliths. Environmental Biology of Fishes, 90: 287-299. doi: 10.1007/s10641010-9742-6.

Cheraghi-Shevi, M., Valinassab, T. \& Hafezieh, M. 2015. Morphological characteristics of lapillus and aging of Plicofollis dussumieri (Ruppell, 1837) from Oman Sea. Iranian Journal of Fisheries Science, 14: 494-502.

Costa, M.L. \& Juras, I.A.G.M. 1981. Determinação da idade e crescimento do bandeirado, Bagre bagre (Linnaeus, 1766). São Luis, Estado do Maranhão. Boletim do Laboratório Hidrobiología, 4: 17-50.

Dan, S.S. 1981. Age and growth in the catfish Tachysurus tenuispinis (Day). Indian Journal of Fisheries, 27(1-2): 220-235. [http://eprints.cmfri.org.in/635/].

Diario Oficial de la Federación (DOF). 2012. Acuerdo por el que se da a conocer la actualización de la carta nacional pesquera. Secretaría de Agricultura, Ganadería, Desarrollo Rural, Pesca y Alimentación, Ciudad de México. [https://www.dof.gob.mx/nota_detalle. php? codigo $=5265388 \&$ fecha $=24 / 08 / 2012]$. Reviewed: July 10, 2020.

Diario Oficial de la Federación (DOF). 2018. Acuerdo por el que se da a conocer la actualización de la carta nacional pesquera. Secretaría de Agricultura, Ganadería, Desarrollo Rural, Pesca y Alimentación, Ciudad de México. [http://dof.gob.mx/nota_detalle.php?codigo $=5525712 \&$ fecha $=11 / 06 / 2018]$. Reviewed: July 10, 2020.

Diogo, R. 2005. Morphological evolution, adaptations, homoplasy, constraints, and evolutionary trends. Catfishes as a case study on general phylogeny and macroevolution. Science Publishers, New Hampshire.

Dmitrenko, E.M. 1975. Size-age composition of the giant catfish Arius thalassinus in the vicinity of Kathiawar Peninsula (India). Journal of Ichthyology, 15: 695702.

Easey, M.W. \& Millner, R.S. 2008. Improved methods for the preparation and staining of thin sections of fish otoliths for age determination. Science Series 
Technical Report No. 143. Centre for Environment, Fisheries and Aquaculture Science, Lowestoft.

Fowler, A. 2009. Age in years from otoliths of adult tropical fish. In: Green, B.S., Mapstone, B.D., Carlos, G. \& Begg, G.A. (Eds.). Tropical fish otoliths: information for assessment, management, and ecology. Reviews: methods and technologies in fish biology and fisheries, Springer, Dordrecht, pp. 55-92.

Flinn, S., Midway, S. \& Ostrowski, A. 2019. Age and growth of hardhead catfish and gaff-topsail catfish in coastal Louisiana, USA. Marine and Coastal Fisheries, 11: 362-371. doi: 10.1002/mcf2.10089

Franks, J.S., Shea, J.L., Brown-Peterson, N.J., Griggs, M.S. \& Larsen, K.M. 2001. Attempts to enhance the visibility and contrast of presumed growth marks on sagittal otoliths from wahoo, Acanthocybium solandri, from the northern Gulf of Mexico and Bimini, Bahamas. Proceedings of the Gulf and Caribbean Fisheries Institute 52nd Annual Meeting, Key West, Florida. Gulf and Caribbean Fisheries Institute, Marathon, pp. 577-585. [http://aquaticcommons.org/ 13442/1/gcfi_52-49.pdf]. Reviewed: July 10, 2020.

Gauldie, R.W. 1993. Polymorphic crystalline structure of fish otoliths. Journal of Morphology, 218: 1-28. doi: 10.1002/jmor. 1052180102

Green, B.S., Mapstone, B., Carlos, G. \& Begg, G.A. (Eds.). 2009. Tropical fish otoliths: information for assessment, management and ecology. Springer, Dordrecht.

Hauser, M., Doria, C.R., Melo, L.R., Santos, A.R., Ayala, D.M., Nogueira, L.D., et al. 2018. Age and growth of the Amazonian migratory catfish Brachyplatystoma rousseauxii in the Madeira River basin before the construction of dams. Neotropical Ichthyology, 16: e170130. doi: 10.1590/1982-0224-20170130

International Council for the Exploration of the Sea (ICES). 2009. Workshop on age reading of European and American eel (WKAREA), Bordeaux, France. ICES-CM 2009\ACOM: 48: 65 pp.

Khan, M.A., Nazir, A. \& Khan, S. 2016. Assessment of growth zones on whole and thin-sectioned otoliths in Sperata aor (Bagridae) inhabiting the River Ganga, India. Journal of Ichthyology, 56: 242-246. doi: $10.1134 / \mathrm{s} 0032945216020041$

López-Martínez, J., Herrera-Valdivia, E., RodríguezRomero, J. \& Hernández-Vázquez, S. 2010. Peces de la fauna de acompañamiento en la pesca industrial de camarón en el Golfo de California, México. Revista de Biología Tropical, 58: 925-942. doi: 10.15517/RBT. V58I2.5255

Lundberg, Y.W., Xu, Y., Thiessen, K.D. \& Kramer, K.L. 2015. Mechanisms of otoconia and otolith development. Developmental Dynamics, 244: 239-253. doi: $10.1002 /$ dvdy. 24195
Maciel, T.R., Vaz-dos-Santos, A.M. \& Vianna, M. 2018. Can otoliths of Genidens genidens (Cuvier 1829) (Siluriformes: Ariidae) reveal differences in life strategies of males and females? Environmental Biology of Fishes, 101: 1589-1598. doi: 10.1007/ s10641-018-0804-5

Madrid-Vera, J., Amezcua, F. \& Morales-Bojórquez, E. 2007. An assessment approach to estimate biomass of fish communities from bycatch data in a tropical shrimp-trawl fishery. Fisheries Research, 83: 81-89. doi: 10.1016/j.fishres.2006.08.026

Maldonado-Coyac, J.A., Sánchez-Cárdenas, R., RamírezPérez, J.S., Salcido-Guevara, L.A. \& Ruiz-Velazco, J.M.J. 2018. La incubación bucal de las crías: un estilo reproductivo de los bagres marinos y de agua dulce. Ciencia y Mar, 65: 35-41.

Marceniuk, A.P. \& Ferraris, C.J. 2003. Family Ariidae (Sea catfishes). In: Reis, R.E., Kullander, S.O. \& Ferraris, C.J. (Eds.). Checklist of the freshwater fishes of South and Central America. Edipucrs, Porto Alegre, pp. 447-455.

Martínez, V.H. \& Monasterio de Gonzo, G.A. 1988. Morfología de otolitos de Heptapterus mustelinus (Valenciennos 1840) (Pimelodidae). Su relación con parámetros dimensionales. Revista de la Asociación de Ciencias Naturales del Litoral, 19: 27-37.

Martínez, V.H. \& Monasterio de Gonzo, G.A. 1991. Clave de identificación de algunos peces Siluriformes en base al estudio de sus otolitos. Revista de la Asociación de Ciencias Naturales del Litoral, 22: 95118.

Mehanna, S.F., Zaki, S., Al-Kharusi, I., Al-Habsi, S. \& AlKiyumi, F. 2012. Stock assessment of the thinspine sea catfish Tachysurus tenuispinis (Day, 1877) in the Arabian Sea, Oman. INOC-CNRS, International conference on land-sea Interactions in the coastal zone. [http://www.inoctr.org/files/bon-livre-des-resumes-dela-conference.pdf]. Reviewed: July 10, 2020.

Miguez, J.S. 2019. Age, growth, and maturity of the gafftopsail catfish, Bagre marinus, in northwest Florida. M.Sc. Thesis, the Florida State University College of Arts and Sciences, Florida.

Morales-Nin, B. \& Aldebert, Y. 1997. Growth of juvenile Merluccius merluccius in the Gulf of Lions (NW Mediterranean) based on otolith microstructure and length-frequency analysis. Fisheries Research, 30: 7785. doi: 10.1016/S0165-7836(96)00553-X

Muro-Torres, V. 2011. Crecimiento y reproducción de los bagres marinos Arius platypogon (Günther, 1864) y Bagre panamensis (Gill, 1883) (Pisces: Ariidae) en el sur de Sinaloa. Tesis de Maestría, Instituto de Ciencias del Mar y Limnología, Mazatlán.

Muro-Torres, V. \& Amezcua, F. 2011. Observations on the reproductive biology of the Chihuil sea catfish in 
the southeast Gulf of California: implications for management. Conservation, ecology, and management of catfish. The Second International Symposium, American Fisheries Society Symposium, 77: 325-333.

Nazir, A. \& Khan, M.A. 2020. Stock-specific assessment of precise age and growth in the long-whiskered catfish Sperata aor from the Ganges River. Marine and Freshwater Research, 71: 1693-1701. doi: 10.1071/ MF19315

Oliveira, C., Diogo, R., Vandewalle, P. \& Chardon, M. 2001. Osteology and myology of the cephalic region and pectoral girdle of Plotosus lineatus, with comments on Plotosidae (Teleostei: Siluriformes) autapomorphies. Journal of Fish Biology, 59: 243-266. doi: 10.1111/j.1095-8649.2001.tb00128.x

Oliveira, A.M., Farina, M., Ludka, I.P. \& Kachar, B. 1996. Vaterite, calcite, and aragonite in the otoliths of three species of piranha. Naturwissenschaften, 83: 133-135. doi: 10.1007/BF01142180

Panfili, J., Tomás, J. \& Morales-Nin, B. 2009. Otolith microstructure in tropical fish. In: Green, B.S., Mapstone, B.D., Carlos, G. \& Begg, G.A. (Eds.). Tropical fish otoliths: information for assessment, management and ecology. Springer, Dordrecht, pp. 212-248.

Panfili, J., Pontual, H., Troadec, H. \& Wright, P.J. (Eds.). 2002. Manual of fish schlerochronology. Ifremer-IRD, Brest.

Peltonen, H., Raitaniemi, J., Parmanne, R., Eklund, J., Nyberg, K. \& Halling, F. 2002. Age determination of Baltic herring from whole otoliths and neutral red stained otolith cross-sections. ICES Journal of Marine Science, 59: 323-332. doi: 10.1006/jmsc.2001.1156

Piddocke, T.P., Butler, G.L., Butcher, P.A., Purcell, S.W., Bucher, D.J. \& Christidis, L. 2015. Age validation in the Lutjanidae: a review. Fisheries Research, 167: 4863. doi: 10.1016/j.fishres.2015.01.016

Pinheiro, P., Broadhurst, M.K., Hazin, F.H.V., Bezerra, T. \& Hamilton, S. 2006. Reproduction in Bagre marinus (Ariidae) off Pernambuco, northeastern Brazil. Journal of Applied Ichthyology, 22: 189-192. doi: 10.1111/ j.1439-0426.2006.00704.x

Pracheil, B.M., George, R. \& Chakoumakos, B.C. 2019. Significance of otolith calcium carbonate crystal structure diversity to microchemistry studies. Reviews in Fish Biology and Fisheries, 29: 569-588. doi: 10.1007/s11160-019-09561-3

Reis, E.G. 1986. Age and growth of the marine catfish, Netuma barba (Siluriformes, Ariidae) in the estuary of the Patos Lagoon (Brazil). Fishery Bulletin, 84: 679686.
Richter, H. \& McDermott, J.G. 1990. The staining of fish otoliths for age determination. Journal of Fish Biology, 36: 773-779. doi: 10.1111/j.1095-8649.1990.tb043 31. $\mathrm{x}$

Rimmer, M.A. \& Merrick, J.R. 1983. A review of reproduction and development in the fork-tailed catfishes (Ariidae). Proceeding of the Linnean Society of New South Wales, 107: 41-50.

Robertson, D.R. \& Allen, G.R. 2015. Peces costeros del Pacífico Oriental Tropical: sistema de información en línea. Versión 2.0 Instituto Smithsonian de Investigaciones Tropicales, Balboa. [https://biogeodb.stri. si.edu/sftep/es/pages]. Reviewed: July 15, 2020.

Santificetur, C., Giaretta, M.B., Conversani, V.R.M., Brenha-Nunes, M.R., Siliprandi, C.C. \& RossiWongtschowski, C.L.D.B. 2017. Atlas of marine bony fish otoliths of southeastern-Southern Brazil, Part VIII: Siluriformes (Ariidae) and Pleuronectiformes (Achiridae, Paralichthyidae, Cynoglossidae). Brazilian Journal of Oceanography, 65: 448-494. doi: 10.1590/ s1679-87592017143106503

Schulz-Mirbach, T., Ladich, F., Plath, M. \& Heß, M. 2018. Enigmatic ear stones: what we know about the functional role and evolution of fish otoliths. Biological Reviews, 94: 457-482. doi: 10.1111/brv.12463

Tilney, R.L. 1990. Aspects of the biology, ecology and population dynamics of Galeichthys feliceps (Valenciennes) and G. ater (Castelnau) (Pisces: Ariidae) off the southeast coast of South Africa. Ph.D. Thesis, Rhodes University, Grahamstown.

Thomas, O.R. \& Swearer, S.E. 2019. Otolith biochemistry, a review. Reviews in Fisheries Science and Aquaculture, 27: 458-489. doi: 10.1080/23308249. 2019.1627285

Tomás, J. \& Panfili, J. 2000. Otolith microstructure examination and growth patterns of Vinciguerria nimbaria (Photichthyidae) in the tropical Atlantic Ocean. Fisheries Research, 46: 131-145. doi: 10.1016/ S0165-7836(00)00140-5

Tomás, J. \& Geffen, A.J. 2003. Morphometry and composition of aragonite and vaterite otoliths of deformed laboratory reared juvenile herring from two populations. Journal of Fish Biology, 63: 1383-1401. doi: 10.1111/j.1095-8649.2003.00245.x

VanderKooy, S.J. 2009. A practical handbook for determining the age of Gulf of Mexico fishes. Gulf States Marine Fisheries Commission, Mississippi. [https://www.gsmfc.org/pubs/ijf/otolith/S_Section\% 20000-02.pdf]. Reviewed: May 15, 2020.

Velasco, G. \& Reis, E.G. 2004. Changes in growth seasonality throughout Netuma barba (Lacépède, 1803) (Siluriformes, Ariidae) ontogeny. Brazilian 
Journal of Biology, 64: 913-914. doi: 10.1590/S151969842004000500024

Velasco, G., Reis, E.G. \& Vieira, J.P. 2007. Calculating growth parameters of Genidens barbus (Siluriformes, Ariidae) using length composition and age data. Journal of Applied Ichthyology, 23: 64-69. doi: 10.1111/j.1439-0426.2006.00793.x

Volpedo, A.V. \& Echeverría, D. 2000. Catálogo y claves de otolitos para la identificación de peces del Mar Argentino. Editorial Dunken, Buenos Aires. [https:// www.researchgate.net/publication/269038893_Catalo go_y_claves_de_otolitos_para_la_identificacion_de_ peces_del_Mar_Argentino]. Reviewed: May 15, 2020.

Volpedo, A.V. \& Vaz-dos-Santos, A.M. 2015. Métodos de estudios con otolitos: principios y aplicaciones. INPA-CONICET-UBA, Buenos Aires.

Received: October 23, 2020; Accepted: January 4, 2021
Volpedo, A.V., Thompson, G.A. \& Avigliano, E. 2017. Atlas de otolitos de peces de Argentina. CAFP-BACAPES, Buenos Aires.

Warburton, K. 1978. Age and growth determination in a marine catfish using an otolith check technique. Journal of Fish Biology, 13: 429-434. doi: 10.1111/ j.1095-8649.1978.tb03451.x

Zar, J. 2010. Biostatistical analysis. Prentice-Hall, New Jersey.

Zavala-Leal, I., Palacios-Salgado, D., Ruiz-Velazco, M., Nieto-Navarro, J.T., Cadena-Roa M.A., DomínguezOjeda, D., et al. 2019. Periodo reproductivo del bagre chihuil Bagre panamensis (Siluriformes: Ariidae) en el sureste del Golfo de California. Revista de Biología Marina y Oceanografía, 54: 21-27. doi: 10.22370/ rbmo.2019.54.1.1459 